METALLURGY AND FOUNDRY ENGINEERING - Vol. 34, 2008, No. 2

\author{
Paweł Chyła***, Sylwia Bednarek***, Aneta Łukaszek-Sołek**, \\ Jan Sińczak*, Piotr Skubisz**
}

\title{
FORGING PROCESS IN THREE TOOL FOLDING DIE
}

\section{INTRODUCTION}

To characterize friction conditions in metal forming processes don't suffice only knowledge about value of friction force or friction coefficient, but whole tribological system is need to be described, that allows to predict final properties of product. Technological lubrication plays particular role in work of tribological system. If selection of basic element of this system, i.e. materials of friction face, it is determined mechanical requirements, in so far as chemical composition of lubricant can be optionally selected depending on function, which it has to fulfill tribological system [1].

It follows in result of realization of technological process influence on less or more intensive tool wear, that causes deterioration of product qualitative feature, mainly growth of surface roughness. By use of properly selected technological lubricants, covering tools by antiadhesive layers, and optimization process parameters, it is possible to decrease in considerable degree frictional resistance and minimize tool wear [2, 3].

Specific conditions of realization of metal forming processes, such as high unit pressure, large deformation one element of frictional couple and expose of clear surfaces, high temperature of deformed metal in forging processes and connected with this high amount of scale, cyclical contact of frictional couple elements afford that to technological lubricants used in metal forming processes stand considerably highest requirements than lubricants used in rubbing machines elements [1, 4].

One of the basic requirements of lubricating medium is resistance on surface pressure and continuity of lubricant layer. High unit pressure occurring in forging processes, require

* Prof. Ph.D., D.Sc., ** Ph.D., *** M.Sc.: Faculty of Metals Engineering and Industrial Computer Sciences, AGH University of Science and Technology, Kraków, Poland; pchyla@metal.agh.edu.pl 
use more effective additions of types EP (extreme pressure). In metal forming processes in consider to high roughness of deformed material surface it is need to use lubricant layer with enough thickness to effectively separate elements of rubbing couple which do not assure e.g. boundary layers in machines elements. Besides, technological lubricants used in metal forming processes must maintain lubrication properties in high temperature [5].

Specific feature of forging processes is occurance of so called open friction node, what cause considerably high consumption of technological lubricant than in typical central friction systems with closed cycle. In metal forming processes lubricant must be inserted after every operation into friction node for example lubricant on the tool surface is carried away by deformed metal. In general lubricant must be removed from product in further stages of metal finishing. Thus, additional requirements are put relatively to technological lubricant, i.e. facility of its remove from product and facility of utilization. Majority of metal forming processes require individual lubrication of tools, what make filling process of the die impression possible. In this paper have been analysed lubrication method depend on independent lubrication of tools, thanks to that obtain improvement in the metal flow in space of die impression of three elements folding $[1,6]$.

\section{NUMERICAL MODELLING}

Lubrication condition influence has been analysed for the forging of flange shown in Figure 1. Forging was done on a mechanical press in the folding die shown in Figure 2. The construction of the dies allows the free movement of the second die along the vertical axis, depending on the phase of the deformation. This makes possible to track the surface friction conditions between deformed material and die impression surface.

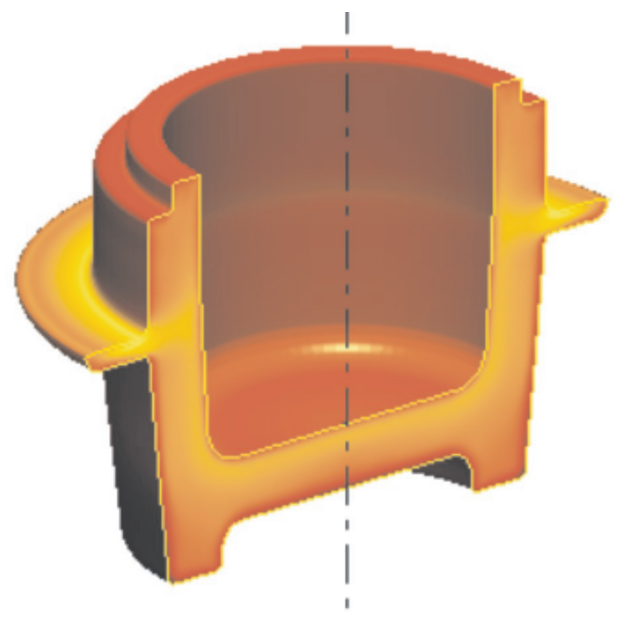

Fig. 1. Model forging of flange made in folding die with movable die insert 


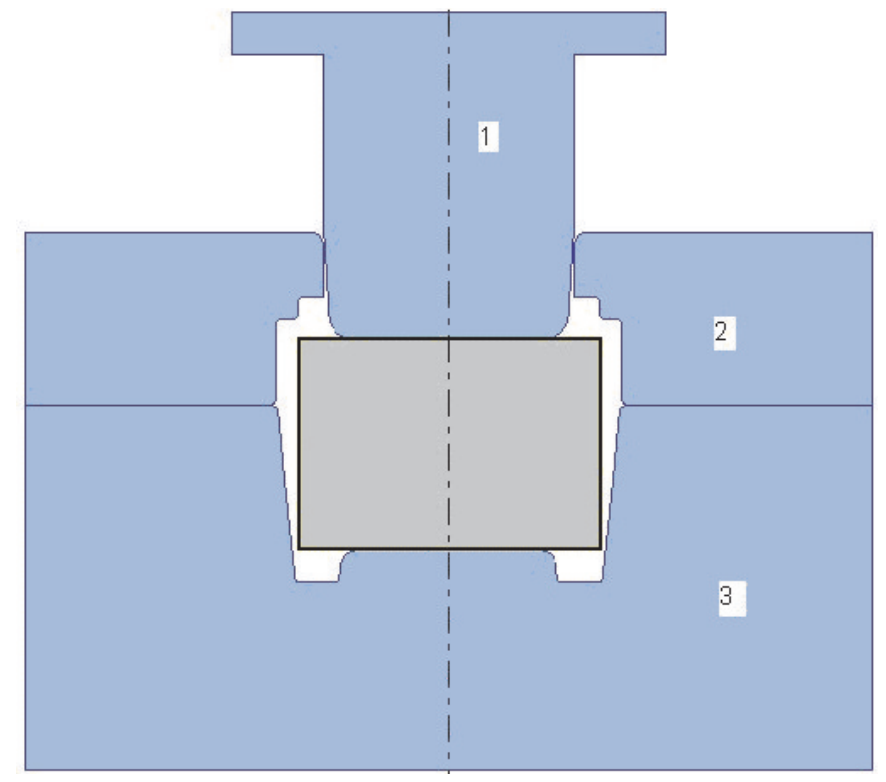

Fig. 2. Construction of three tool die: 1 - piercer, 2 - movable insert with upper resistance mechanism $0.05 \mathrm{MN} / \mathrm{mm}, 3$ - bottom die

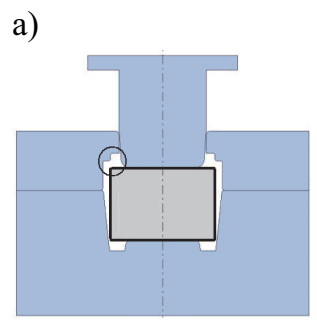

b)

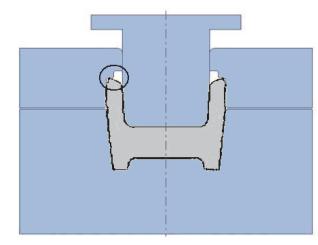

c)

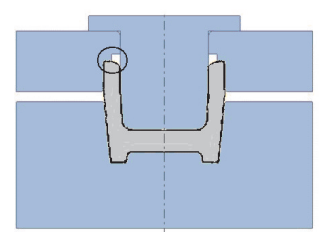

d)

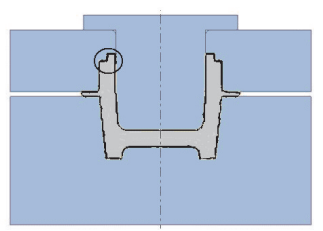

Fig. 3. Next stages of flange forging: a) process beginnig; b) stage of forces equilibrium between spring of movable insert and metal displaced to the top; c) simultaneous displacement of 1 and 2 die to the bottom; d) end of forging process

Following stages of flange forging shown in Figure 3. Second die displace when contact with deformed material to the top, when pressure on die will be equal $0.05 \mathrm{MN} / \mathrm{mm}$. Material overflow is compensated by flash forming in space between second ant third die, when second die displace to bottom by first die (piercer). System characteristic: instrumentation three tool die - mechanical press is shown in Figure 4.

The computer simulations were carried out with a use of commercial code QForm3D, based on the finite element method and rigid-viscoplastic model of body. Calculations were made for axisymmetric strain state. 


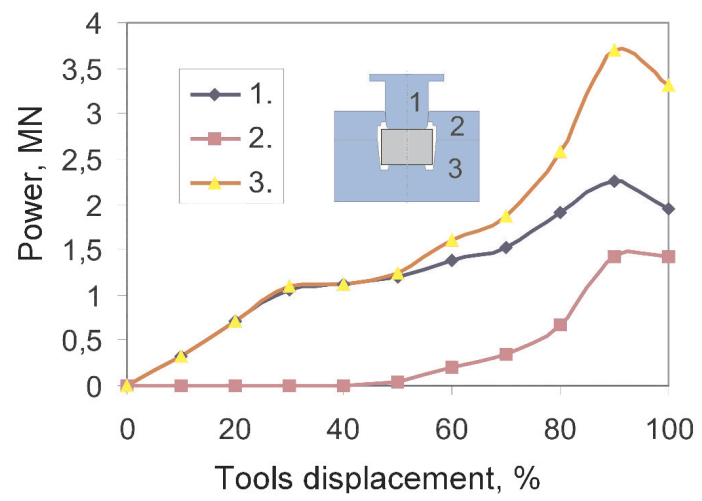

Fig. 4. Characteristic of press with movable elastic insert 1, 2, 3 -value of force in function of tool displacement

In order to determine lubrication conditions influence on the filling process of the die impression, numerical calculations performed for unalloyed steel containing $0.2 \%$ carbon. The stock heat temperature $1100^{\circ} \mathrm{C}$, and the temperature of tools $300^{\circ} \mathrm{C}$. Cross-bar velocity assumed constant, equal to $10 \mathrm{~mm} / \mathrm{s}$. Variable friction conditions applied on the contact surface between deformed metal and die by the following options for friction factor $\mathrm{m}$ :

a) die 1 i 2 - lubricant $(\mathrm{m}=0.1)$, die 3 lubricant $(\mathrm{m}=0.1)$;

b) die 1 i 2 - lubricant $(\mathrm{m}=0.4)$, die 3 lubricant $(\mathrm{m}=0.4)$;

c) die 1 i 2 - lubricant $(\mathrm{m}=0.8)$, die 3 lubricant $(\mathrm{m}=0.8)$;

d) die 1 i 2 - lubricant $(\mathrm{m}=0.1)$, die 3 lubricant $(\mathrm{m}=0.8)$;

e) die 1 i 2 - lubricant $(\mathrm{m}=0.8)$, die 3 lubricant $(\mathrm{m}=0.1)$.

In case, where friction factor amount 0.1 accepted that parts od dies where lubricated by spray-gun. While for tools which weren't lubricated, accepted friction factor amount 0.8 . To compare friction factor influence were used intermediate value $(\mathrm{m}=0.4)$. Following variants were proposed: d) lubrication of 1, 2 die and die 3 wasn't lubricated and wariant e) wherein were used opposite lubrication method than in variant d).

\section{ANALYSIS OF RESULTS}

As criterion of lubrication quality was accepted latest metal filling area (fig. 5). Results of numerical modelling accounts that area and process power parameters are show in Figures 6-11.

Follow from results of numerical modeling presented in Figures 6-11, that filling of die impression of upper die and correct forging shape is determined lubrication quality in that area. Besides correct filling of die impression (Fig. 6) obtain more favourable strain 
distribution (Fig. 7) and uniform metal displacement in forging volume (Figs. 8, 9), what prevent local tool wear. Good lubrication of upper tools reduce total pressure on tools (Fig. 10) and consistently plastic work quantity (Fig. 11), at simultaneously correct shape of final product.

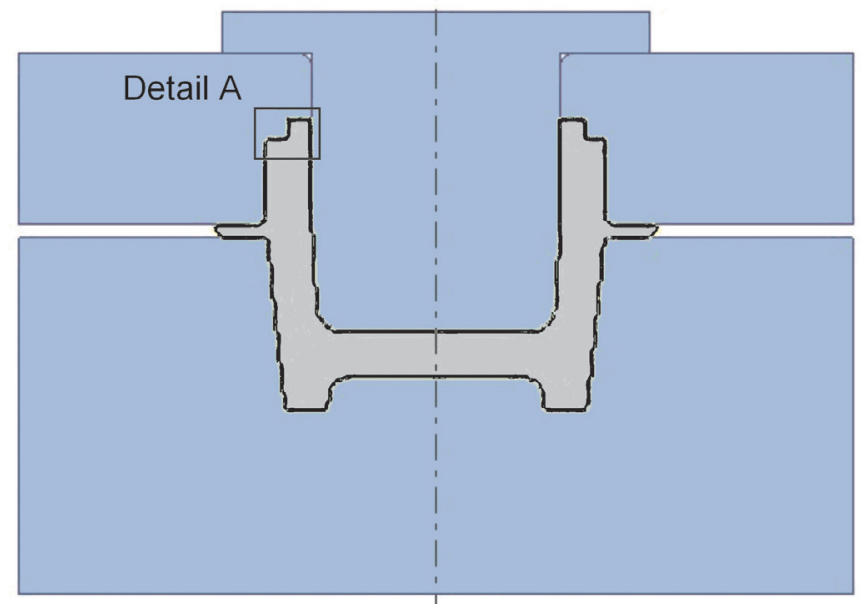

Fig. 5. Latest metal filling area

a)

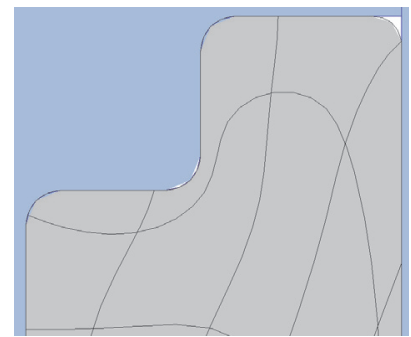

d)

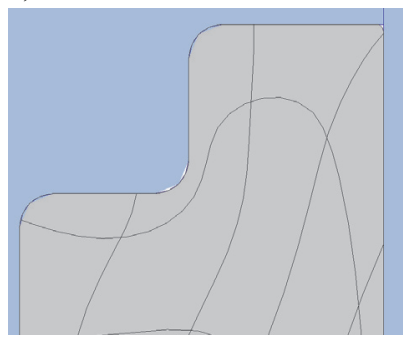

b)

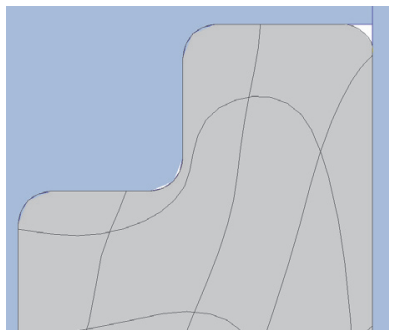

e) c)
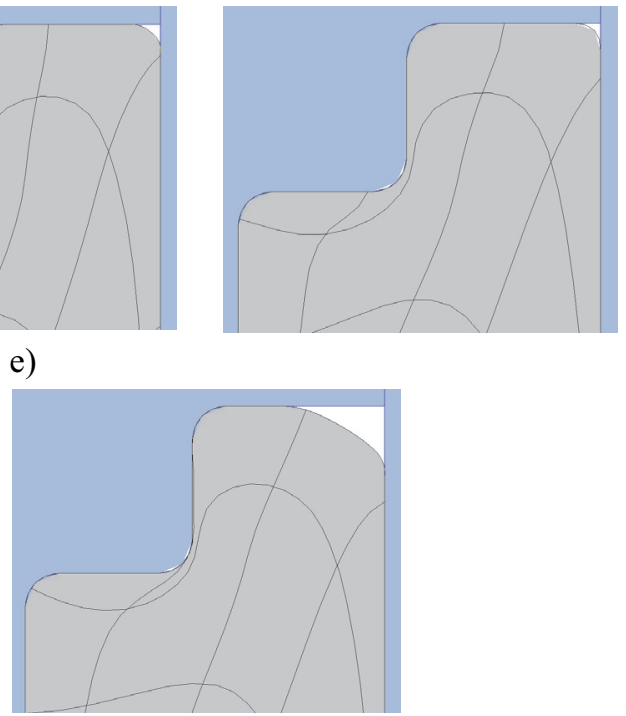

Fig. 6. Filling of the die impression dependence on lubrication conditions: a) die 1 i $2-m=0.1$, die $3-m=0.1$; b) die 1 i $2-m=0.4$, die $3-m=0.4$; c) die 1 i $2-m=0.8$, die $3-m=0.8$; d) die 1 i $2-m=0.1$, die $3-m=0.8$; e) die 1 i $2-m=0.8$, die $3-m=0.1$ 
a)

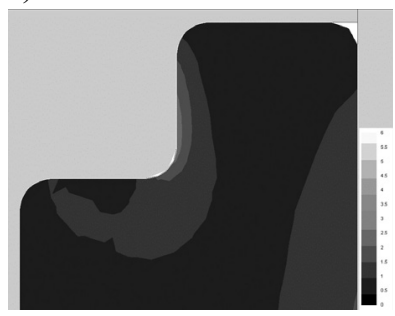

d)

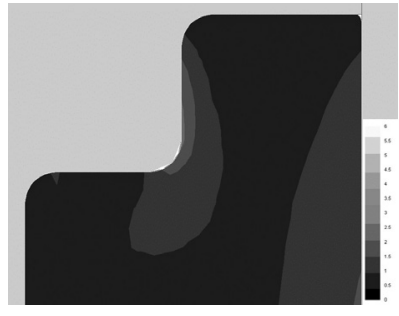

b)

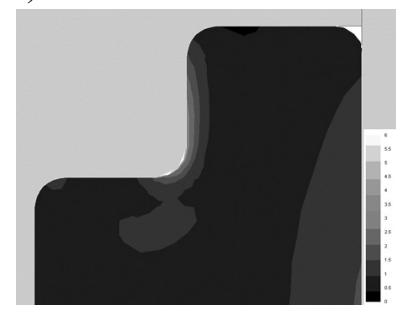

c)

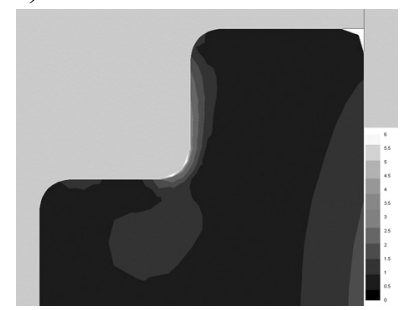

e)

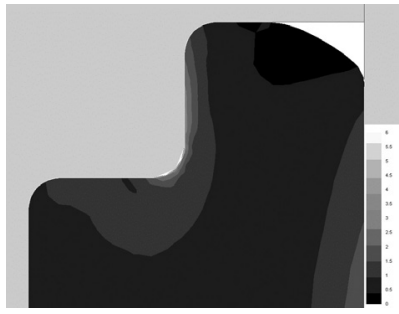

Fig. 7. Effective strain distribution dependence on lubrication conditions: a) die 1 i $2-m=0.1$, die $3-m=0.1$; b) die $1 i 2-m=0.4$, die $3-m=0.4$; c) die $1 i 2-m=0.8$, die $3-m=0.8 ; d$ ) die $1 i$ $2-m=0.1$, die $3-m=0.8$; e) die 1 i $2-m=0.8$, die $3-m=0.1$

a)

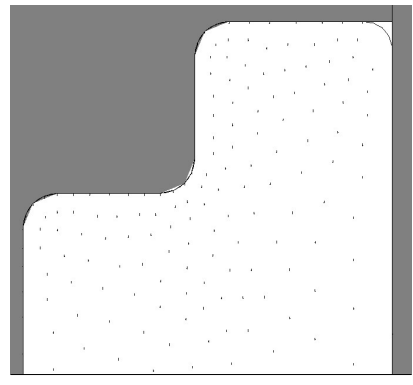

b)

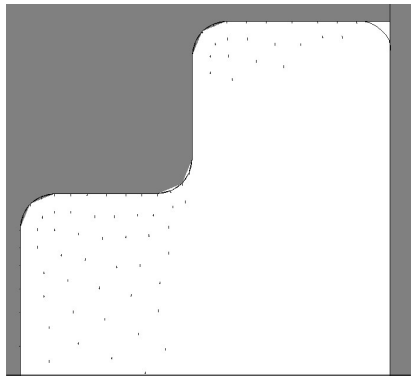

c)

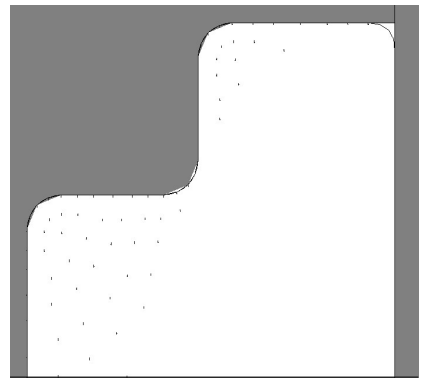

d)

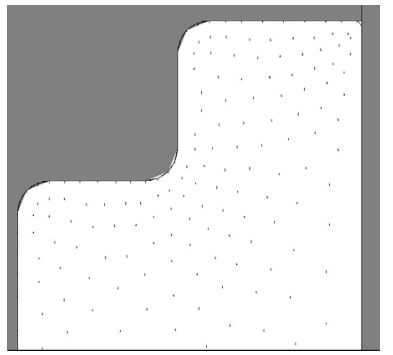

e)

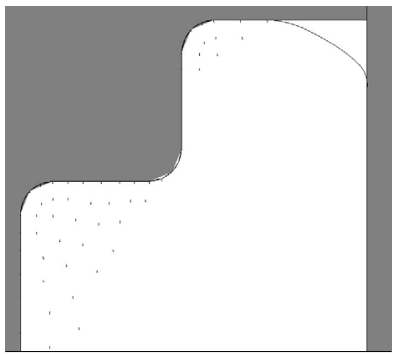

Fig. 8. Vectors of the metal displacement for various friction factors in the last forging stage: a) die 1 $i 2-m=0.1$, die $3-m=0.1$; b) die 1 i $2-m=0.4$, die $3-m=0.4$; c) die $1 i 2-m=0.8$, die $3-m$ $=0.8$; d) die 1 i $2-m=0.1$, die $3-m=0.8$; e) die 1 i $2-m=0.8$, die $3-m=0.1$ 
a)

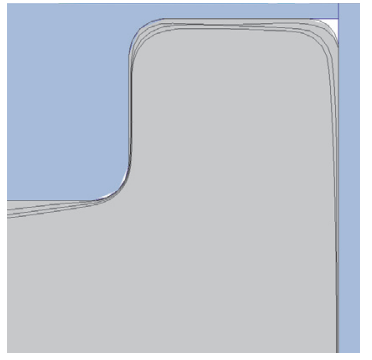

d)

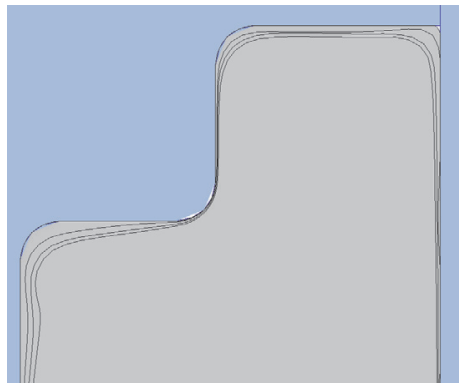

b)

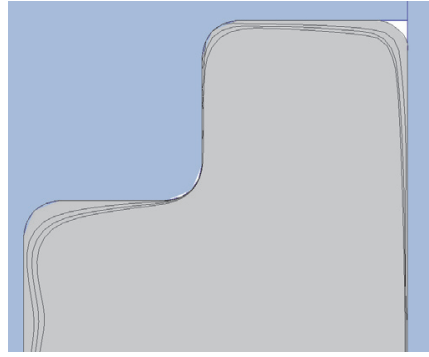

e)

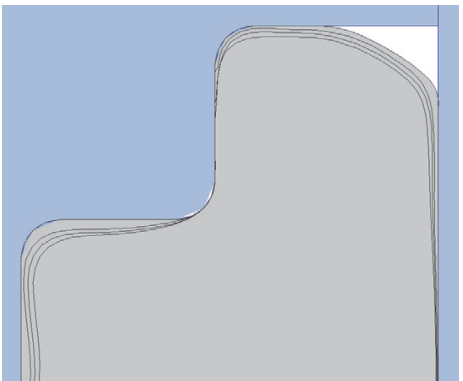

Fig. 9. Lubrication conditions influence on undersurface flow lines of forging: a) die 1 i $2-m=0.1$, die $3-m=0.1$; b) die 1 i $2-m=0.4$, die $3-m=0.4$; c) die 1 i $2-m=0.8$, die $3-m=0.8$; d) die 1 i $2-m=0.1$, die $3-m=0.8$; e) die 1 i $2-m=0.8$, die $3-m=0.1$

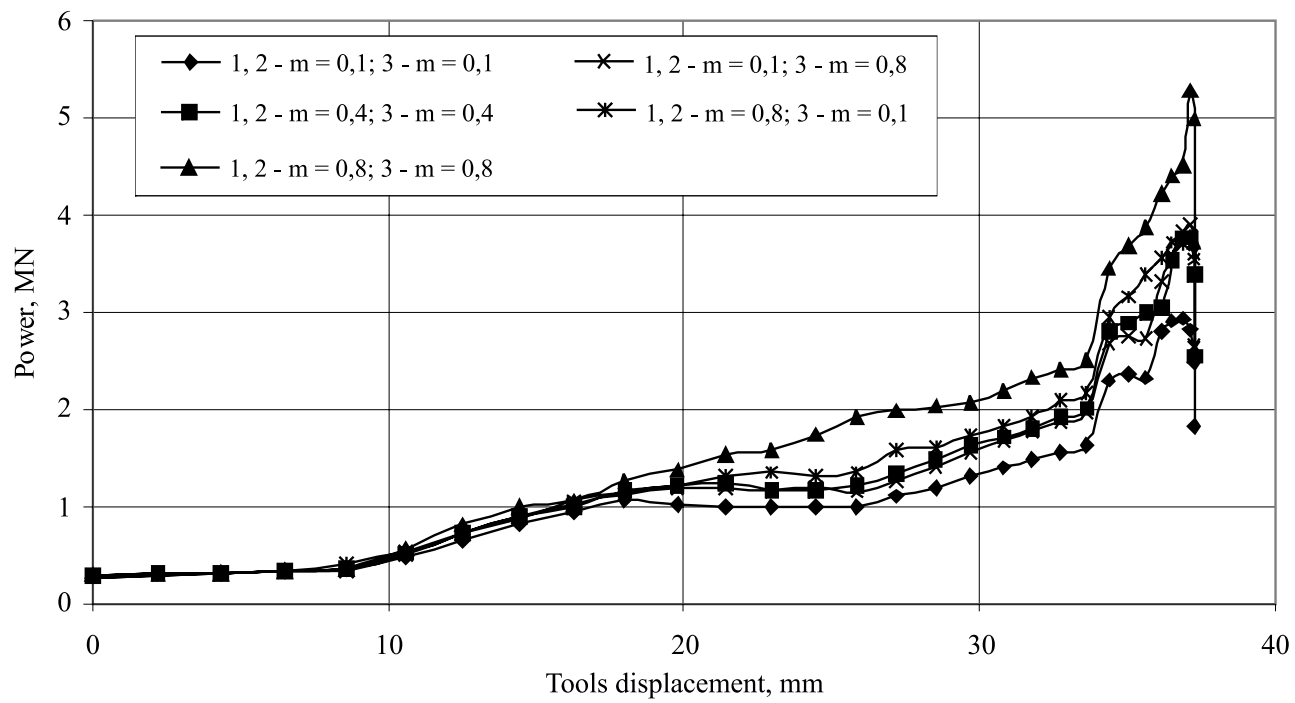

Fig. 10. Friction factor influence on power for five variants of lubrication method 


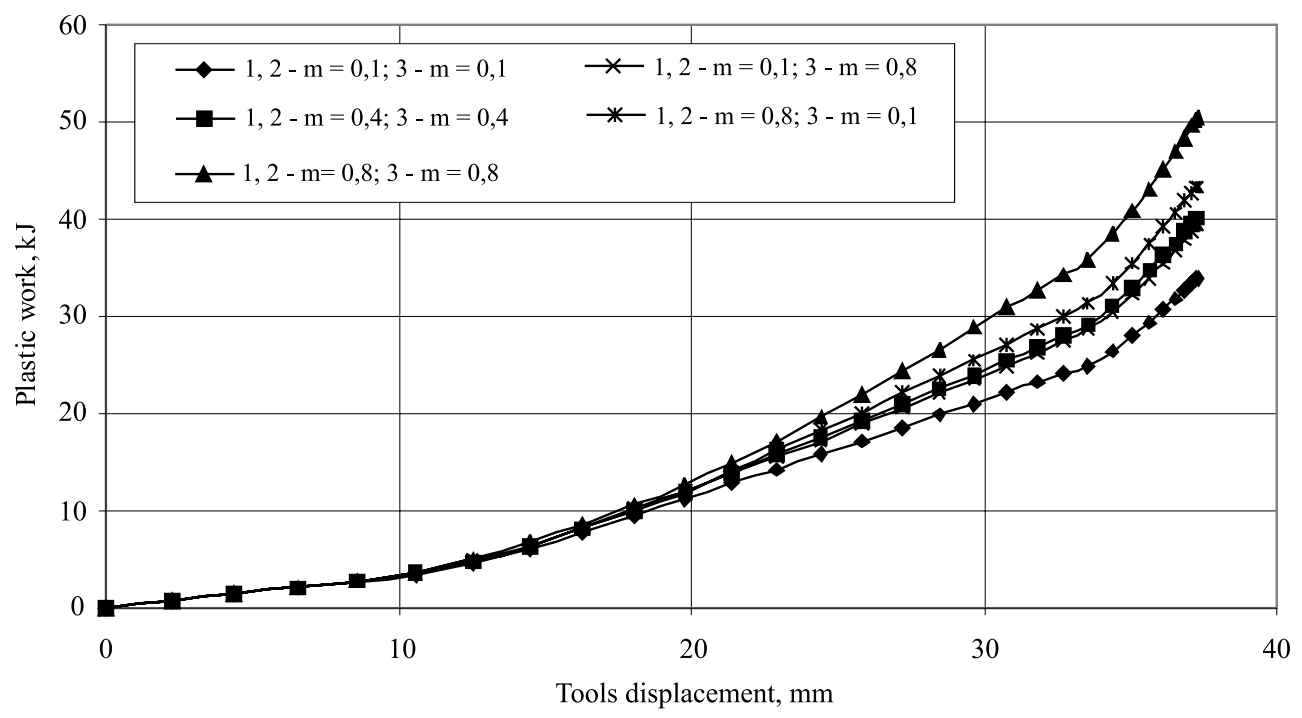

Fig. 11. Plastic work for the flange forging for five variants of lubrication method

\section{CONCLUSION}

Influence of lubrication conditions were analyze for the flange forging, forging process was carried out on mechanical press with folding die. Dies design enable for displacement of movable insert optionally along vertical axis, dependence on forging process stage. That make possible tracking surface friction conditions influence between deformed material and tool surface. Filling of upper die impression and correct shape of forging is determined by quality of lubrication in that area. To do his it is need to use so called regulate lubrication. Except correct filling of die impression obtain more favourable strain distribution and uniform metal displacement in entire volume, what prevent local tool wear. Good lubrication upper tools reduce pressure on tools and total plastic work with assurance correct shape of final product.

\section{Acknowledgments}

This work is supported by the MNiSW, project no 11.11.110.859.

\section{REFERENCE}

[1] Lacki P.: Zastosowanie wybranych modeli tarcia w numerycznej analizie procesów obróbki plastycznej. Konferencja nt. „Informatyka w technologii metali”. Zakopane 11-14 stycznia 2004 r. Wyd. Nauk. „Akapit”, Kraków, 2004

[2] Behrens A., Schafstall H.: 2D and 3D simulation of complex multistage forging processes by use of adaptive friction coefficient. J. Mat. Proc. Technol., vol. 80-81, 1998 
[3] Dobrucki W., Odrzywołek E.: Analiza metod wyznaczania współczynnika tarcia między narzędziem i metalem w stanie płynięcia plastycznego, opartych na procesie spęczania. Obr. Plast., nr 4, 1979

[4] Gierzyńska-Dolna M., Adamus J.: Rola i zadania smarów technologicznych w procesach obróbki plastycznej metali. Prz. Mech. nr 16, 1995

[5] Seidel H.: The use of die lubricants in the forging of ferrous and non-ferrous metals. Metallurgia, vol. 69, nr 2, 2002

[6] Kocańda A., Świłto S.: Zastosowanie modelowania fizycznego w pomiarach przemieszczeń względnych. Konferencja nt. Fizyczne i Matematyczne Modelowanie Procesów Obróbki Plastycznej. Warszawa 1718.05.2001 (PAN) Warszawa, 2001

Received

December 2008 